\title{
Impacts of COVID-19 on food production, environment and the economy: Review
}

\author{
Alimamy Fornah ${ }^{*}, 1$, Antony Miller ${ }^{1}$, Phillip Hamilton ${ }^{1}$ and Josephus F. Borsuah ${ }^{2}$
}

${ }^{1}$ Department of Agriculture, Biology and Health Sciences, Cameron University, 73505 Lawton, OK, USA

${ }^{2}$ School of Natural Resources, University of Nebraska-Lincoln, 68583-0726, Lincoln, NE, USA

*Corresponding Author

Received: 18 Oct 2020; Received in revised form: 8 Nov 2020; Accepted: 9 Nov 2020; Available online: 13 Nov 2020

\begin{abstract}
The world is hit by another pandemic that has created a global threat. The Coronavirus disease of 2019 (COVID-19) has affected the entire human existence. The virus has taken over 1 million lives within 10 months. Governments are scrambling with different laws and regulations such as shelter-in-place orders, curfew, social distancing, mask-wearing, cancellation of public events, and traveling bans. These guidelines have helped reduce the spread and transmission of the virus in many countries, including some states in America. However, the virus has not only impacted lives, it has severally touched the agriculture, economy, and environment as well. This paper reviews the historical, origin, and mode of transmission of the COVID-19 and its impacts on human activities. On food production, it has created massive food insecurity around the world, especially in developing economies, resulting to collapse of small businesses and rising unemployment. Similarly, the environment has been largely impacted by improving ambient air quality and contributing to global waste management problems. Overall, the rate of increase in both atmospheric carbon dioxide $\left(\mathrm{CO}_{2}\right)$ and nitrogen dioxide $\left(\mathrm{NO}_{2}\right)$ dropped. On the other hand, the planet has seen over 200 metric tons of medical waste per day since the outbreak of the virus. Finally, doctors, scientists and farmers need to work together to reduce the impact of COVID-19 on human survival in all aspects. Therefore, this paper provides review of the COVID-19 pandemic, its effect on humans, environment, economy, agriculture, employment, and the potential mitigations to address the challenges of the pandemic in the near future.
\end{abstract}

Keyword-Coronavirus pandemic, COVID-19, impact, agriculture, economy and environment.

\section{INTRODUCTION}

Coronavirus disease 2019 (COVID-19) is an infectious disease caused by severe acute respiratory syndrome coronavirus 2 (SARS-CoV-2), a novel member of the coronavirus family which was first reported by the World Health Organization (WHO) on December $31^{\text {st }}, 2019$ (WHO, 2020a). The mode of transmission was initially unknown, it has since been established that the SARS-CoV-2 virus is welladapted for human-to-human transmission, and it is suspected that airborne transmission is the primary mode of transmission (Burke, 2020; Chen, 2020; Ghinai, 2020; Huang, 2020a; Li, 2020; Liu, 2020 Phan, 2020). The virus has so far taken the lives of over 1,000,000 people. The COVID-19 pandemic has negatively affected our planet and human activities. For instance, the poor agricultural productivity recorded across all continents, low economic activities - from the operation of major factories and businesses, and the halt in movement worldwide is debilitating. Several studies have been conducted on the COVID-19 infection, including its types, origin, mode of transmission, and health impact on humans. However, information on its impact on the environment, agricultural activities, economy, and unemployment is limited. Therefore, the objective of this review is to provide information on the impact of COVID-19 on global food production, economic activities, and environment.

\subsection{Origin and history of the COVID-19 pandemic}

Given that the COVID-19 is an emerging disease, there are a number of questions regarding its origin and 
history. The SARS-CoV-2 virus is of natural origin and is thought to have originated from bats prior to having evolved the capability to infect humans (Andersen, 2020; Boni, 2020; Wan, 2020). The first cases of the disease were reported in Wuhan, China, and was linked with the Wuhan Huanan Seafood Market (Huang, 2020a; Wu, 2020; Zhou, 2020). From these observations, it shows that SARS-CoV-2, the causative agent of the current COVID-19 pandemic, is a novel, naturally-occurring virus likely of zoonotic origin with epidemiological data indicating Wuhan, China as the source of the current outbreak.

The first case to be reported outside mainland China occurred on January $13^{\text {th }}, 2020$, infecting a Chinese tourist in Thailand (Hui, 2020). The first case of the COVID-19 in the United States (U.S.) was reported on January 20 $0^{\text {th }}, 2020$ (Holshue, 2020). In sub-Saharan Africa (SSA) countries, the first case was reported on January $28^{\text {th }}, 2020$ (Adepoju, 2020). The appearance of the disease was shortly followed by an explosive increase in confirmed cases reported from 21 different countries, including China, the U.S. and SSA countries. These events ultimately led to a declaration of the outbreak as a Public Health Emergency of International Concern (PHEIC) by the WHO on January $30^{\text {th }}, 2020$ (Bassetti, 2020; WHO, 2020b), and the declaration of COVID-19 as a pandemic by the WHO on March $11^{\text {th }}, 2020$ (Cucinotta, 2020). Cases in China are thought to have peaked in late January or early February 2020 (Callaway, 2020; Cyranoski, 2020), while cases in both the U.S. and SSA countries continue to rise. As at the time of this preparing this manuscript (26 October 2020), China was reported to have 62 cumulative cases per one million population, the U.S. was reported to have 24,367 cumulative cases per one million population, and SSA countries combined was reported to have11,891 cumulative cases per one million population (WHO, 2020c).

\subsection{Transmission and containment of the virus}

The symptoms of a SARS-CoV-2 infection appears after an incubation period of approximately 5 days $(\mathrm{Li}, 2020)$, and several recent reports have found strong evidence of asymptomatic transmission of the virus, although it is not yet clear whether asymptomatic transmission is a major factor in the spread of the disease (Huang, 2020b). Overall, these observations indicate that individuals can be infectious prior to being diagnosed with the disease, and that the virus easily moves from one individual to another individual.

\subsection{Current and Future Considerations}

The designation of COVID-19 as a pandemic has been in place for approximately six months at the time of this manuscript preparation. Currently, epidemiologists around the world are working on models to better prepare and prevent the spread of SARS-SoV-2 in both short-term and long-term projections (Scudellari, 2020). While these predictions do not always align, the models do agree that the COVID-19 is not going away in the foreseeable future. Though there remain many unknowns and the future remains uncertain even with the most accurate models, we do have a better understanding of the virus than we did in December 2019.

For example, we know that the spread of the disease differs depending on countries and locations. Recent reports have indicated that asymptomatic carriers could potentially pass the virus to other individuals, without knowing they have done so. This 'silent transmission' of SARS-CoV-2 indicates a need for rapid, reliable contact tracing methods and isolation of individual cases in order to suppress future outbreaks (Moghadas, 2020). We have also seen many countries implement drastic measures in an attempt to control the spread of the virus, including shutdowns/lockdowns, curfews, required quarantines, and travel restrictions, in response to the rapid rise in cases and the ease with which the virus has spread. These measures, along with physical distancing and self-isolation have led to a dramatic reduction in the spread of the virus, and therefore the number of cases in those parts of the world that have implemented them (Maier, 2020).

In addition to these, several efforts have been launched to develop a vaccine against SARS-CoV-2 infection. While the development of an efficacious vaccine against SARS-CoV-2 is critical in reducing the number of deaths and the spread of the disease, none have been approved for widespread use in the public as at the time of this manuscript preparation. There are several clinical trials designed to assess the efficacy and safety of potential vaccines currently in progress (Amanat, 2020). Despite worldwide efforts to accelerate the development of a safe and effective vaccine, current estimates maintain that successful administration of a SARS-CoV-2 vaccine is months, and perhaps years to come (Amanat, 2020; O'Callaghan, 2020). Therefore, the near-term course of the pandemic will largely depend on the response of affected communities. The long-term course of the pandemic will largely depend on the arrival of a successful vaccine that will be accessible and affordable by all countries. 


\section{IMPACT OF COVID-19 ON FOOD PRODUCTION}

The COVID-19 pandemic has caused a lot of disruption in food production, distribution, and consumption across the world. The disruption caused by the pandemic has led to a significant impact on food prices and is a major concern to a world with such rapidly expanding human population (Torero, 2020). According to Global Food Crisis Report (2020), approximately 83 million to 132 million people may go to bed hungry due to the COVID-19 pandemic. These effects cut across the entire globe, but most significantly, countries with low economic GDP hit the hardest (Laborde et al., 2020a). It affects all sectors of agriculture, including poultry, livestock, and crop production. The pandemic has also affected the availability and access to food (Laborde et al., 2020a). This is partly due to lack of on-farm personnel, inability to import food, and the abrupt ending of school feeding programs that many school children rely on as a source of meal (Headey and Ruel, 2020).

On-farm production has seen an increase in unharvested or decomposing agricultural products due to labor shortage and closure of restaurants, and lack of transport within the borders of countries. The downside of this increase in food wastage extends from loss of income for the producers to global climate change through the emission of greenhouse gases (Aldaco et al., 2020; Goeb et al., 2020). However, it is also projected that many urban dwellers in developing countries could return to rural areas to take up farming as an alternative source of food and income (Laborde et al. 2020b). This is because of the loss of jobs associated with strict enforcement of COVID-19 lockdowns to curb down the spread of the virus.

Most of the agricultural industries worldwide have struggled to maintain personnel due to the COVID-19 outbreak. This has caused loopholes in the food supply chain, especially in Africa, where most of the farmers are subsistent with little or no farm equipment. These smallholder farmers rely on relative or family members, community youths, or religious societies to help with ploughing, planting, weeding, and harvesting along the production chain. The lockdowns, quarantine, isolation, and death have placed restrictions on labor, food processing, and transportation affected the lack of personnel. This effect extended to the animal and meat processing industries. These animals are forced to stay longer in the farms with limited feed resources leading to animal shrinkage in weight and loss of lives.

International travel restrictions between countries have posed a severe threat to food security, especially in the importdependent countries (Cullen, 2020). These restrictions across different countries have limited agricultural food trade between countries because of the pandemic (Laborde, 2020). Limitations in food export and import causes a break in the production supply chain (Ivanov, 2020), which is threatening food security around the globe. The COVID-19 pandemic impact have severely affected the vulnerable people in the poorest nations (FAO, 2020). A widespread media coverage highlighted that the COVID-19 outbreak forced large scale farmers in the United States and Canada to dump their milk on the street. It was estimated that dairy farmers in the United States dumped about four million gallons of milk every day due to breakage in the milk supply chain, from the COVID19 pandemic shutdown (Forstadt, 2020).

Similarly, Nepalese farmers had to dumped milk products worth \$ 17 million and a lot more in deterioration (NepaliSansar, 2020). In Peru, producers are left with no option but to dump their white cocoa in landfills because hotels and restaurant that buys their product are closed. In India, farmers in rural areas are forced to feed strawberries to cows due to a lack of transportation to the city markets (Torero, 2020). In China, cattle are starving due to the unavailability of food and workforce labor due to the COVID19 shutdown (Zhang, 2020). The United States, Canada, France, Germany, Italy, and Australia depend on seasonal foreign workers from North Africa and Eastern Europe to work on farms (Torero, 2020). Movement restriction disturbed food production, transportation, and distribution (figure 1) (Poudel et. al. 2020), while reducing labor availability; hence, food prices increase due to high demand and low supply. 


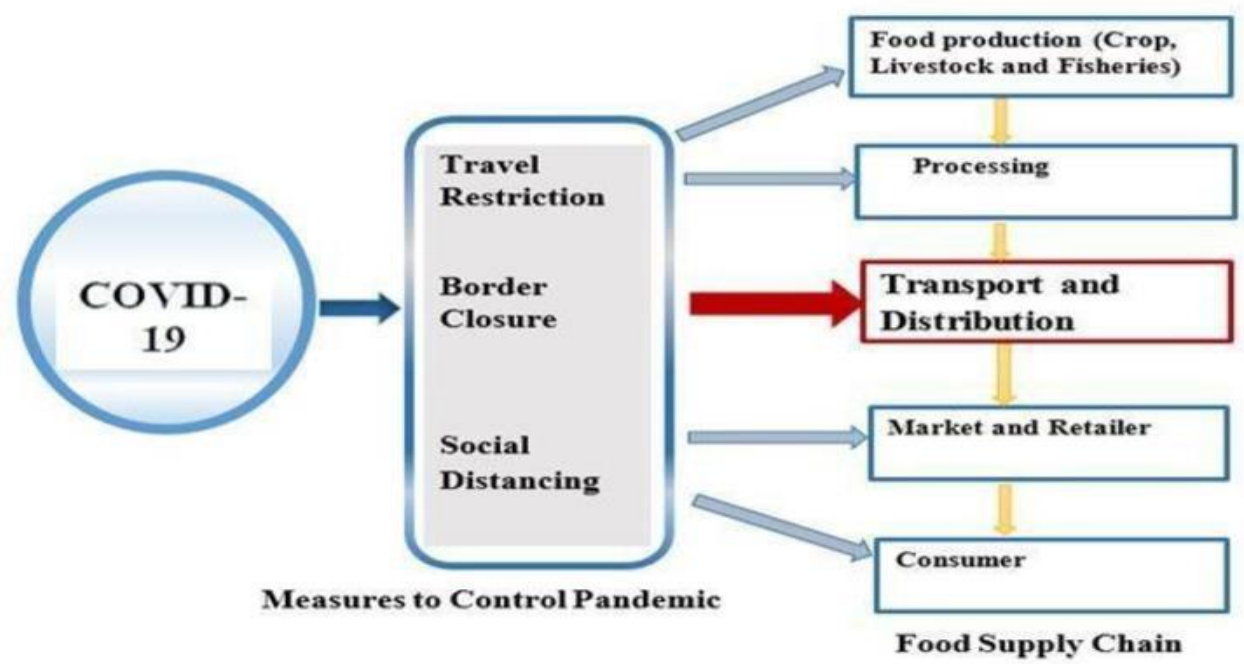

Fig.1: This figure shows COVID-19 affecting every stage of the food supply chain with a major impact on food transportation and distribution taken from Poudel et al., 2020.

\section{POSITIVE IMPACT ON THE ENVIRONMENT}

Due to bans on travel and orders to stay indoors to prevent the spread of COVID-19, researchers see a decrease in carbon emissions across the world in the U.S., China, and India. It is believed that environmental pollution dropped in these areas because of the pandemic (Henriques, 2020). Many small businesses shutdown or suspended production thereby reducing the negative impacts of the operations of these businesses on the environment. Depending on how long the pandemic lasts, it may contribute to an overall decrease in the yearly total of emissions, which will benefit the environment.

According to Jacinta Bowler, a scientific journalist at Science Alert, there is a clear positive impact on the environment (Bowler, 2020). Unfortunately, it is casually related to the lockdowns of different countries around the world. Bowler stated, "Resource economist Marshall Burke did some back-of-the-envelope calculations about recent air pollution drops over parts of China." (Bowler, 2020). Considering air pollution as a harm to the environment, physicist Jos Lelieveld states that "air pollution exceeds malaria as a global cause of premature death by a factor of 19 " (Cassella, 2020). The pandemic has caused massive lockdowns, leading to a drop in $\mathrm{CO}_{2}$ emissions, not just in China, but also around the world. It is worth noting that air pollution is a major contributor to global warming.
In Italy, canals have become apparent and dolphins are back in their waters. Researchers at Columbia University say that " $\mathrm{CO}_{2}$ emissions are falling sharply," and "air pollution caused by vehicles in New York has been reduced by $50 \%$ from last year" (McGrath, 2020). Possibly, we can find ways to continue these positive impacts on the environment after the virus diminished.

Another positive effect that is more global in scale is the reduction of Carbon and Nitrogen emissions due to the halting of major transportation systems during the crisis. With fewer people traveling by car, and even fewer by airplane, global greenhouse gas emissions (GHG) has significantly dropped. According to the urbanism and city planning website Citylab, transportation usage is down from as low as 35\% for San Francisco's Metropolitan Transport Authority (MTA), to as high as $90 \%$ with New York City's MTA (Bliss, 2020). These numbers suggest that many harmful emissions are curtailed for as long as the virus affects major metropolitan areas of the nation, benefitting the environment for the time being.

\subsection{How COVID-19 affected the environment in China?}

Greenhouse gas emissions were reduced by about $25 \%$ in the weeks following the Chinese New Year at the peak of the COVID-19 outbreak in China (Myllyvirta, 2020). Li 
Shuo of Greenpeace China is concerned that the stimulus plan envisioned by the government will lead to industrial projects that might reverse these reductions (Network, 2020). Not only did greenhouse gas emissions lower, but air quality significantly improved. Nitrogen dioxide $\left(\mathrm{NO}_{2}\right)$ is a pollutant that primarily gets into the air from burning fuel and is linked to asthma and respiratory infections (EPA, 2020). This famous image gathered from satellite data indicates the reduction in $\mathrm{NO}_{2}$ emissions before the COVID-19 outbreak and during the worst outbreak in China when many people in most major cities were asked to stay inside and not leave their homes (figure 2).

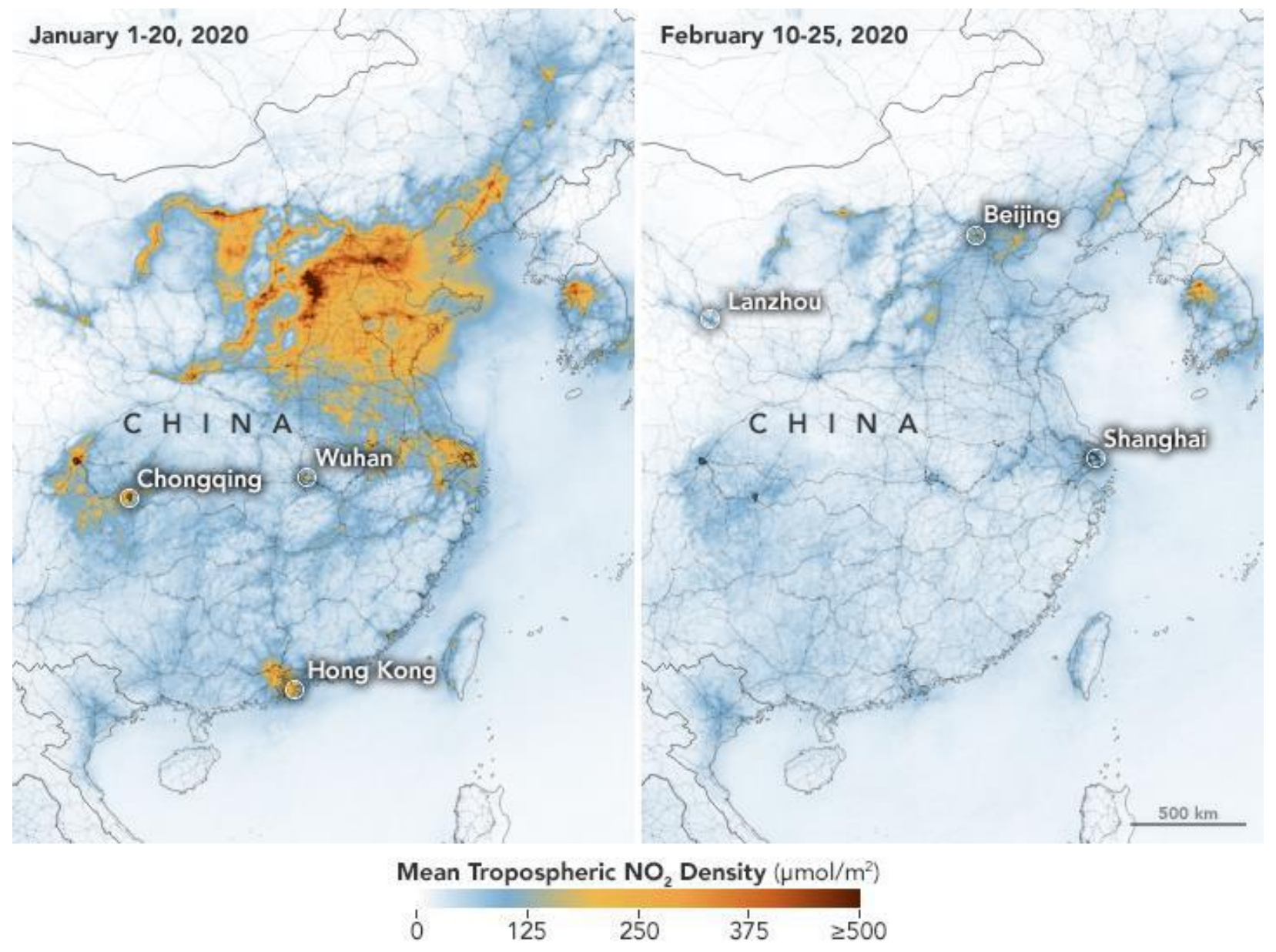

Fig.2: This figure shows the airborne nitrogen dioxide plummets over China during COVID-19 lockdown (Tan, Chou, Liang, Chou, \& Shiu, 2009)

Despite improvements in air quality, notably in China and in Europe due to stay at home orders, the environmental side effects from the Coronavirus have not all been positive. For example, recycling programs and centers in both U.S. and Europe have been closed, disposable bag bans have been overturned, and the amount of medical waste produced is rising (Bloomberg News, 2020).

\subsection{Air Pollution}

Is air pollution a big deal? Air pollution is one of the world's biggest environmental problems. Five million deaths per year are attributable to air pollution (Figure 3) (Ritchie and Roser, 2019). 


\section{Share of deaths from air pollution, 2017}

Share of deaths which are attributed to total air pollution - outdoor and indoor - as a risk factor.
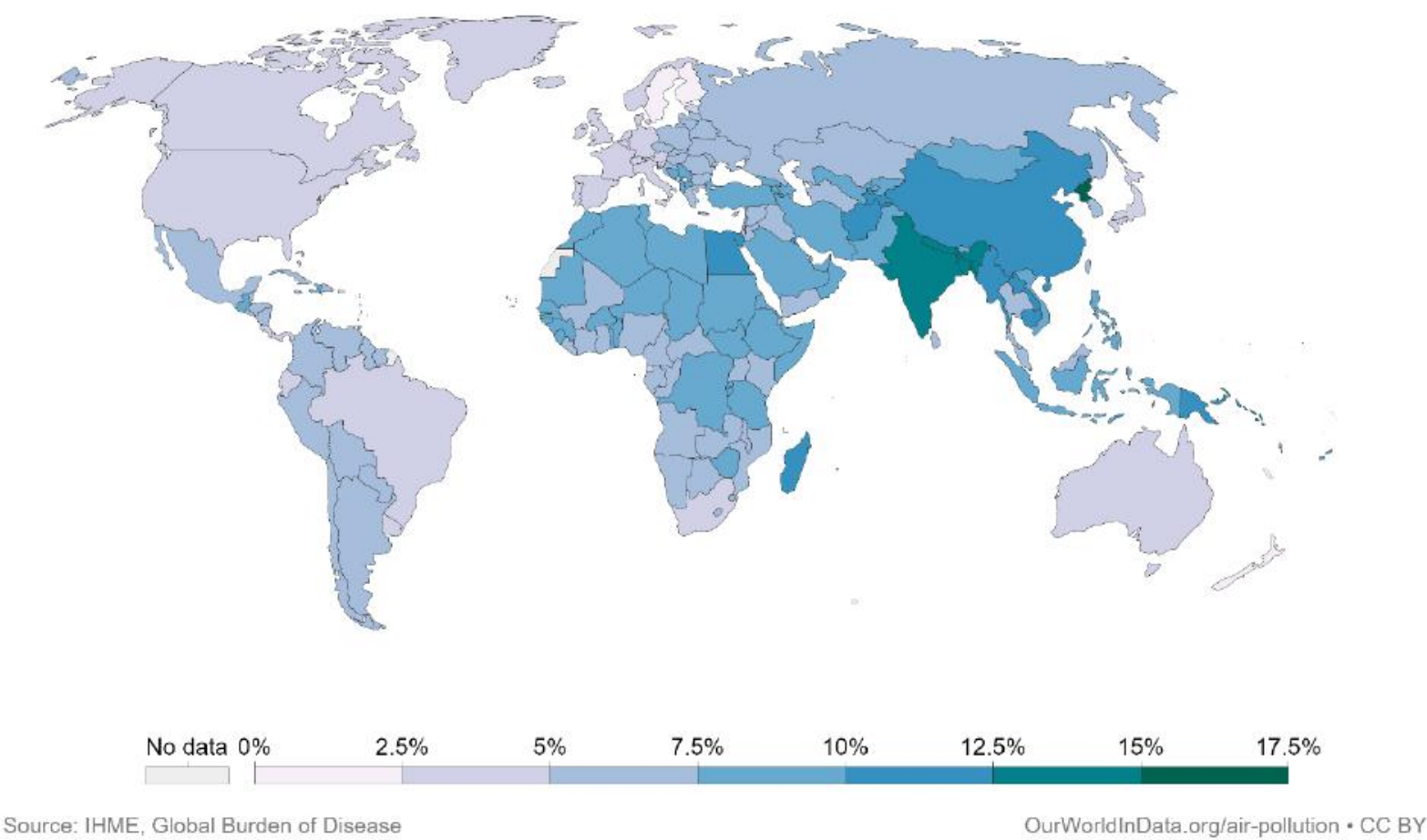

Fig.3: This figure shows the share of deaths from air pollution in 2017 (Ritchie \& Roser, 2017)

While death rates in developed countries are low, air pollution exacerbates and makes other conditions worse. In the United States, for example, almost $4 \%$ of deaths can be attributable to air pollution. In China, this figure is much higher, at $11 \%$. One researcher estimated that the coronavirus lockdown in China, which resulted in hundreds of millions of people staying home and thousands of factory closures, could have saved as many as 70,000 lives by curbing emissions from factories and vehicles (Burke, 2020).

\subsection{Negative Impact on the Environment}

A tremendous amount of medical wastes has been produced because of the COVID-19 pandemic. According the Verge Report, hospitals in Wuhan China are generating six times as much medical waste as compares to pre pandemic level. Wuhan is producing over 200 tons of medical waste per day and China has invested on building mobile medical waste disposable centers (theverge.com, 2020; chinadaily.com, 2020). As a planet, we already have tremendous trouble with waste management, often producing over three times more garbage than we can properly dispose of in just the United States. That waste usually ends up in the ocean - obstructing and harming wildlife and polluting the environments where the trash lays. We know, for instance, that hazardous waste is something that has the potential to harm human life (biohazardous needles, toxic sludge, etc.) and that this waste is not naturally present in the human environment, but rather is produced based on manufacturing efforts to advance our society (EPA, 2006).

Though air and water may be cleaner and clearer while pandemic protections are in place, it may be worse for the environment in the long run. People may simply be delaying trips, and when travel bans are lifted, the surge of travel could increase the level of pollution to pre-pandemic levels. Industrial pollution will also return to normal when businesses are back on track. There are also concerns that while people are changing their habits now with travel and work, environmental sustainability discussions could be pushed to the background (Henriques, 2020). Short-term 
gains may be a reason to delay enacting more substantial, longer-lasting solutions.

One of the top ways Coronavirus can have negatively impacted the environment is by the abrupt increase in personal consumption of energy. Entire families at homes all day and night, in most cases means multiple television and computer monitors, lighted rooms, running inside and out to play, all of which cause an increase in energy usage. Another negative impact is the increase of single-use plastics. During this pandemic, if you walk through any store across the United States, all the shelves are cleared of paper and plastic plates, plastic cups, plastic silverware, and water bottles. The Plastic Industry Association is trying to get the single-use plastic bag ban reversed. They are saying reusable bags can spread the virus, so they are asking for these bans on bags to be reversed and to increase single-use plastics. According to NRDC.org, in "New York, 23 billion plastic bags are used by residents each year." Increase in single-use plastic can increase pollution in our waterways and land significantly (NRDC, 2020).

There are also some unfortunate side effects brought with all the positives. One negative effect is that companies and groups previously heavily involved in green initiatives have been forced to put on hold their environmental operations. For example, as Politico reports, the European Union has postponed climate law debates, Fridays for Future protests are forced online (Politico reports, 2020), and many industries that produce high amounts of carbon emissions are seeking government bailouts (theguardian.com, 2020). Of great concern to these activists is the fact that it is highly likely that post-recession, the world will see a large surge in emissions, possibly negating the positive reduction changes brought by COVID-19. Gernot Wagner, a clinical associate professor at New York University's Department of Environmental Studies, adds to the concerns over in addressing MIT's Technology Review: "Emissions in China are down because the economy has stopped and people are dying, and because poor people are not able to get medicine and food. This is not an analogy for how we want to decrease emissions from climate change" (Temple, 2020).

An article from Politico also notes a very real environmental threat that is increasing as the quarantine protocols continue - a heavy increase in waste production (Heath, 2020). Companies like Starbucks have switched from their reusable cups, deciding instead to serve their drinks in single-use cups that are not recyclable. Other restaurants that have transitioned to providing curbside or delivery options must provide packets of plastic utensils since their customers cannot enter the building to use metal silverware at their inside tables, such increase in the production and usage of plastic enormous and dangerous for the environment. Even worse than the restaurant plastic issues, medical facilities are producing exceedingly high amounts of waste (Jiangtao \& Zheng, 2020). This "mountain of medical waste," as they label it, is mostly comprised of single-use items such as face masks and other personal protective equipment. Unfortunately, not only are these items piling up by the millions, but the incinerators used to dispose of them safely are quickly being overwhelmed - despite new construction in hundreds. These as well as medical waste facilities reaching the end of their viable lifespan, are causing extreme concern for the ability of many countries including the United States to contain the virus and prevent another outbreak. Will these problems also overwhelm other developing countries or will China's example spur proactive handling of such waste that will prevent the pandemic from becoming an even more significant threat to the environment? Only time will tell.

\subsection{Positive Impact on the Economy}

There may be significant economic growth amid the chaos and confusion created by the COVID-19 pandemic in the coming years. As we have seen, OPEC $^{1}$ has cut oil prices in the wake of COVID-19, and that has being reflected in reduced global oil prices. For instance, Oklahoma have seen gasoline price dropped to as low as $\$ 1.37$ per gallon - far lower than it has been in years. This is due to OPEC ceasing their typical price gouging operations on oil barrels to support international economies during this challenging time (Forbes, 2020). This means that those interested in the stock market are more likely going to notice this trend and invest money into petroleum and refined gas markets, which will soar directly after the COVID-19 crisis is mitigated and oil prices return to new normal levels. It will more likely be a tight window to get money out of the market once OPEC does its price-fixing, but if pulled correctly, many investors may see a massive return on their investments.

Another positive impact is that we have learned that work could be more efficient and effective through virtual means than we might ever thought. 


\subsection{Negative Impact on the Economy}

The extent of economic damage is dependent on the length of time that the damage-causing entity can flourish (CSIS, 2020). Those that are most likely to be affected are countries that are heavily hit by the Covid-19 pandemic. The most impacted industries are recognized as global air carriers and entertainment industries such as theatres, restaurants, casinos, and others, since social distancing prevents maximum utilization of these resources' customers (CSIS, 2020). Much of the world has experienced locked down or travel restrictions or quarantines measures to reduce the spread of the virus, but these restrictions may have come too little, too late to prevent intra-national spreading. Corporations involved in these two industries have suffered massive revenue loss, and there have already been massive layoffs and reduced spending in order to preserve the operation of corporations in the long run across other sectors such as manufacturing and mining.

In terms of the economy, COVID-19 has forced the closure of many small and large businesses in both developing and developed economies. For instance, in the US there exist a lot of uncertainty about the economy because closed businesses results to massive job loss culminating into lower incomes and decreased economic activity. On a larger scale, the government stimulus packages to heavily affected people in the United States are not enough to cushion the economic stress and frustrations caused by the Coronavirus pandemic. Medical care, health insurance, and paid sick leave should be the goals of businesses to help people survive the fallout (Waller, 2020). The severity of economic ramifications depends on how long the pandemic lasts in epic maleficence. Many taxpayers and voters are rethinking "Medicare for all" since they lost their jobs that provided their health insurance coverage. However, many who did not have company health insurance often saw their insurance premiums double and do not want the changes.

Gross Domestic Product (GDP) is an important measure of how well a country is doing since it represents all finished goods and services completed during a designated period. If we look at the following graph (figure 4), we note that COVID-19 ended the longest economic expansion on record.

\section{Longest Economic Expansion on Record Ended by COVID-19}

\section{Length of expansions in months}

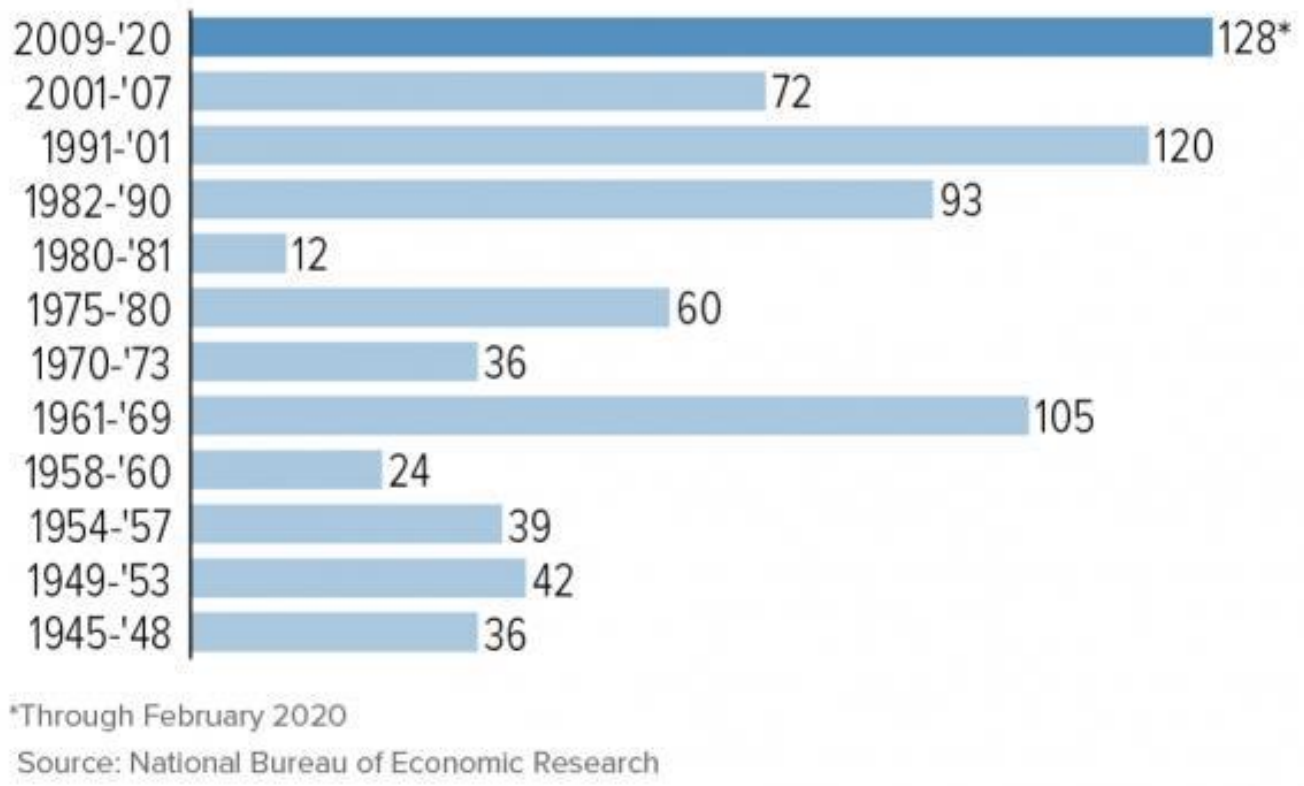

Fig.4: This figure shows the length of economic expansion on record ended by COVID-19 (Research, 2020) 
In the United States, while the expansion was long, both the economy's average annual growth rate and the typical worker's earnings gains were relatively modest by the standards of earlier long expansions. President Donald Trump claimed that his policies would produce a substantial and sustained increase in economic growth, and his appointed Council of Economic Advisers believed that those policies would boost wages and employment substantially. By contrast, the Congressional Budget Office (CBO) and many other non-partisan analysts projected much slower economic growth and smaller increases in most workers' earnings.

The real GDP (adjusted for inflation) growth rate is shown in the following graph. Note that most quarters are positive, with two small negatives in 2011 and 2014. However, post-Covid-19 indicates that the United States is in a recession with strongly negative GDP growth for two quarters in a row after the start of the pandemic (Figure 5).

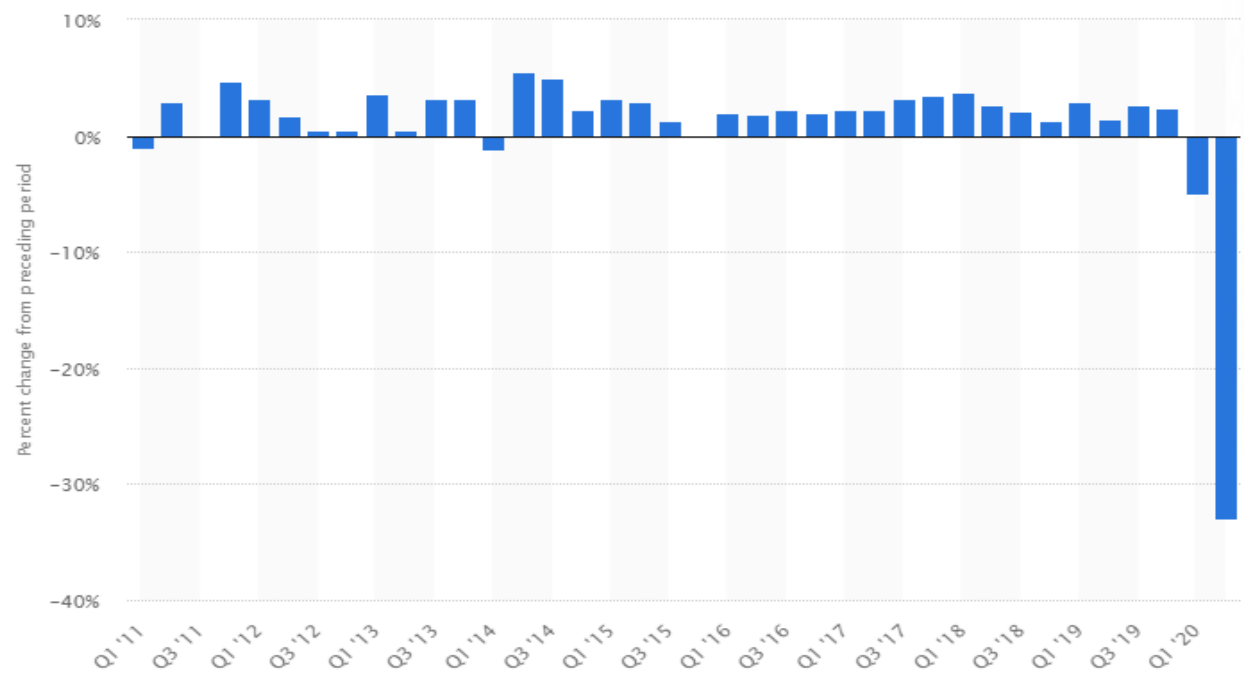

Fig.5: This figure show the quarterly growth of the real GDP in the United States from 2011 to 2020 (Duffin, 2020a)

Monthly unemployment is another important gauge of the economic health of a nation. The graph below indicates that after the shutdown of the economy that resulted from Covid-19 that unemployment rates skyrocketed (Figure 6).

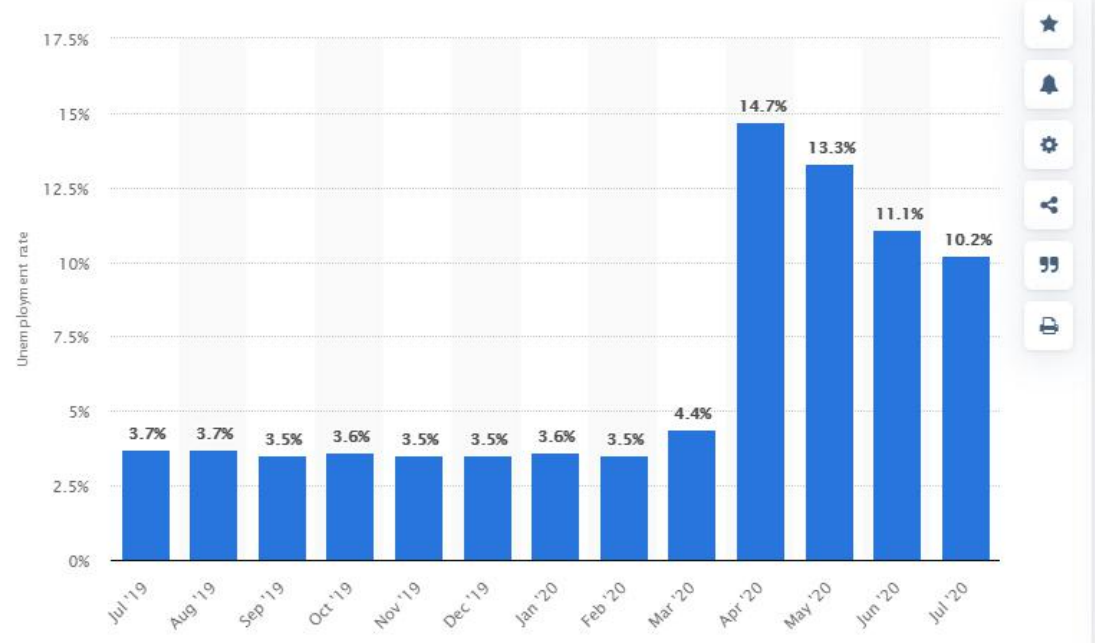

Fig.6: This figure shows the monthly unemployment rate in the United States from July 2019 to July 2020 (seasonally adjusted)

(Duffin, 2020b)

ISSN : 2456-1878 
Casual observers look at the stock market as the only barometer of the U.S. economy's health. They believe that wealthy investors know how well the economy is performing in all categories and that the stock market will rise and fall according to how well the economy is doing. However, investors are fickler than that and follow trends more readily than macroeconomists do. They often overlook factors such as workers losing health insurance, workers working either less than 40 hours or holding two or more jobs, and the impact of undocumented workers on our labor force. The following graph depicts what has happened to the U.S. Dow Jones Industrials stocks during the year 2020 after the introduction of the Covid-19 pandemic (figure 7). The index bottomed out in March when most of the country was placed in a lockdown, and deaths from the virus started increasing. However, as time goes on, the investors renewed their faith that their investments are sound. A large part of the large bounce back in the stock market is that the Federal government has pumped over three trillion dollars into the economy. It is noteworthy that many economists and significant investors believe that the market is overvalued and will decline regardless of the influence of COVID-19.

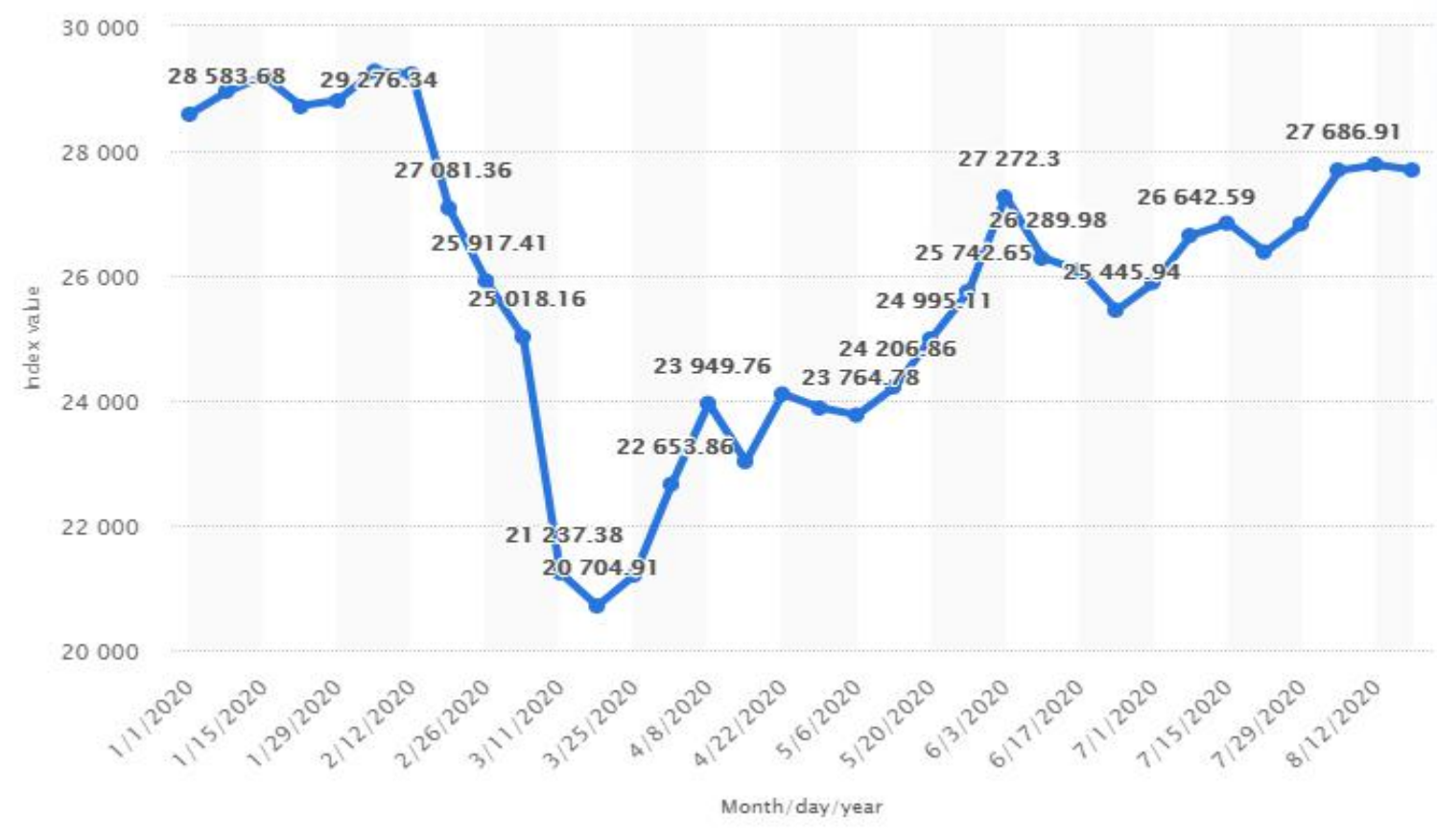

Fig.7: This figure show the weekly development of the Dow Jones Industrial Average index from January 2020 to August 2020 (Rudden, 2020)

Aside from the environmental impact the virus has had globally, it has also damaged many facets of the international economy; as it continues to spread to more and more countries, these effects are likely to increase exponentially as well. The infographic and data visualization website Visual Capitalist provide data on the economic impact China is facing, as well as predictions on the effects the U.S. and other countries may face next. As the data suggests, China's Economic Indicators - Investment in Fixed Assets, Retail Sales, Value of Exports, and Production - are all down in Year-over-Year change by at least 13\%, with Investment hit the hardest at $-24.5 \%$ (Ross, 2020). Although these numbers should increase as China continues its path to recovery, the country still faces heavy issues in product and service demand. International demand is negatively affected since an oversupply of goods is created due to other nations currently dealing with the outbreak, while local issues cause domestic demand to decrease sharply. A survey conducted in Beijing indicates, "up to $65 \%$ of respondents plan to 'restrain' their spending habits after the virus" (Ross, 2020).

ISSN : 2456-1878 
Another problem for the economy is the companies that are switching their production and purpose of manufacturing medical and safety supplies for hospitals and other medical personnel (Ward, 2020). Among these companies are Ford, GE, General Motors, Dyson, and many more. While this is a great show of solidarity and support for the heroes that continue to sacrifice personal safety in fighting the virus, it could also have a negative effect in that products and services, mostly non-essential, are put at a halt. While the non-essentials are obviously a required sacrifice that will not significantly impact everyday life, it is still a factor that moves the economy further down into economic recession, as the new supplies are not producing as much revenue for these companies. This will more than likely drive prices up, as well as providing a hard-to-meet level of demand from consumers when production resumes post-crisis.

\subsection{The Impact of Covid-19 in America}

Many schools are no longer in session or have modified teaching formats across America and much of the developed world; stock markets are in free-fall; millions of Americans in the hospitality industry have already lost their jobs, leading to the largest number of unemployment claims in a single week since the United States (U.S.) has had unemployment insurance (figure 8) (Forbes.com, 2020a).

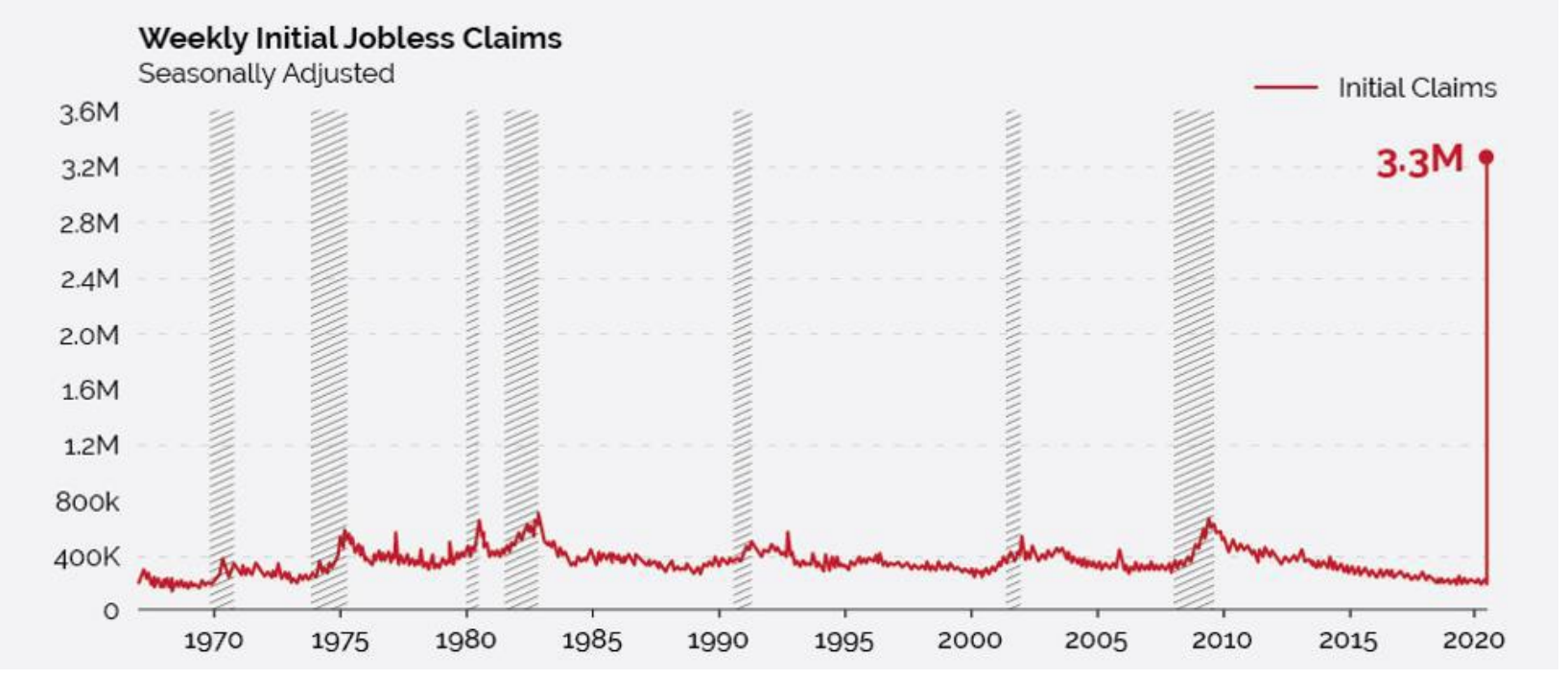

Fig.8: This figure shows the jobless claims over the years in the United States (Jones, 2020)

Leading economists suggest this is only the beginning of a recession ${ }^{2}$; many Americans believe a depression is likely (Jones, 2020). Questions may include: What has caused this economic catastrophe? Are there any side effects the people at Forbes are overlooking because these benefits and costs are not accounted for in the economy? What happens to the environment when certain segments of an economy shutdown?

Negative impact on the economy is coming in many different forms: from the stock market dropping, thousands of people losing their jobs, people not buying what and how they usually buy, and supply chains being disrupted. According to Forbes.com (2020), "Nearly 50\% of companies say they are at least somewhat likely to conduct layoffs over the next three months due to coronavirus COVID-19, while more than onethird of firms (37\%) say they already have instituted a hiring freeze.

\section{CONCLUSION}

Businesses are closing, once-bustling streets are often nearly empty, and there is so much air of uncertainty encircling the globe while people obey quarantine restrictions meant to keep them safe. A global pandemic of the novel coronavirus COVID-19 has affected the world medically, socially, environmentally, and economically. As this pandemic continues, people must find new ways to cope with 
the far-reaching effects and help slow its spread, which is vital in preventing more deaths.

The COVID-19 pandemic has negatively and positively affected our planet. Countries across the world are drastically changing their operations as a way of mitigating the impact of the virus on their population. Slow responders to the virus are being heavily hit. The most egregious example is the United States, where the sudden impact of the virus was met too late with action; the number of infected cases quickly grew to a massive peak of over 5.5 million, with the highest death toll of any country to date - more than 210, 000 people dead. According to public health experts, if the virus does continue this trend - or even worse, mutate and take on even more severe qualities - the human population worldwide could face a massive shock not seen since before the medical Revolution. On the hopeful side though, people from every corners of the world and every community are gaining an acute, experiential knowledge of what is and could be facing our global environment. It is worth noting the countries such as New Zealand, South Korea and Japan have done exemplary well in curtailing the devastating impact of the virus on their population.

COVID-19 may exacerbate global food shortage at a magnitude never seen before due to the economic recession hovering over many countries around the world. Currently, 690 million people may go to bed hungry, and this pandemic can cause this number to increase at a minimum of 773 million people (FAO, 2020). This year, farmers might not plant enough food to sustain the entire world population. Therefore, governments need to help farmers with input (seeds, fertilizers, pesticides, machinery, and animal feed), especially in low-income countries. Since the fertilizer industry in China has been affected by COVID-19 (Marlow, 2020), nations must start thinking about producing fertilizers such as organic fertilizers, which are cheap and affordable for smallholder farmers. Also, governments need to support farmers with storage facilities to preserve their produce until distributed. In addition, transportation should be provided so farmers can transport their goods to bigger cities for sale. Politicians need to strengthen international relationships to import and export food between countries. If not, COVID-19 will increase food insecurity by disrupting food production and distribution (Siche, 2020). If we do not help farmers plant enough food this year, the impact will be enormous next year. The starvation number will double whiles exposing children and adults to other diseases due to weak immune systems. The solutions to food shortages will have to be a concerted effort between politicians, scientists, and farmers. COVID-19 and many agricultural, economic, and environmental problems are too big to be dealt with on an individual level. They require the coordination of people, governments, and industry all working together towards a common goal.

\section{ACKNOWLEDGEMENT}

All the inputs and help provided by the co-authors and all the student in Dr. Fornahs' Environmental Science Class at Cameron University are appreciated. The contributions from Shamsu Mustapha at Easy Solar Sierra Leone and Lawrence Aula at Oklahoma State University are highly appreciated.

\section{REFERENCES}

[1] Adepoju, P., (2020). Nigeria responds to COVID-19; first case detected in sub-Saharan Africa. Nature Medicine (26) 444-448.

[2] Aldaco, R., Hoehn, D., Laso, J., Margallo, M., Ruiz-Salmón, J., Cristobal, J., Kahhat, R., Villanueva-Rey, P., Bala, A., Batlle-Bayer, L. and Fullana-I-Palmer, P., (2020). Food waste management during the COVID-19 outbreak: a holistic climate, economic and nutritional approach. Science of The Total Environment, 742, p.140524.

[3] Amanat, F. and Krammer, F. SARS-CoV-2 Vaccines: Status Report (2020) Immunity (52) 583-589.

[4] Andersen, K. G., Rambaut, A., Lipkin, W. I., Holmes, E. C., and Garry, R. F. (2020). The Proximal Origin and SARS-CoV2. Nature Medicine, 26, 450-452.

[5] Bassetti, M., Vena, A., and Giacobbe, D. R. (2020). The novel Chinese coronavirus (2019-nCoV) infections: Challenges for fighting the storm. European Journal of Clinical Investigation (50) https://doi.org/10.1111/eci.13209

[6] Bliss, L. (2020, March 20). When the World Stops Moving. Retrieved from https://www.citylab.com/transportation/2020/03/coronavirusimpact-public-transit-street-traffic-data-trains/607915/

[7] Bloomberg News. (2020, March 30). Bloomberg Green. Retrieved from The Unexpected Environmental Consequences of Covid-19: https://www.bloomberg.com/news/articles/202003-30/the-unexpected-environmental-consequences-of-covid19

[8] Boni, M. F., Lemey, P., Jiang, X., Lam, T. T-Y., Perry, B. W., Castoe, T. A., Rambaut, A., and Robertson, D. L. (2020). Evolutionary origins of the SARS-CoV-2 sarbecovirus lineage responsible for the COVID-19 outbreak. Nature Microbiogy, 2020 https://doi.org/10.1038/s41564-020-077-4.

[9] Bowler, J (2020). New Evidence Show How COVID-19 Has Affected Global Air Pollution. https://www.sciencealert.com/here-s-what-covid-19-is-doingto-our-pollution-levels 
[10] Burke, M. (2020, March 8). COVID-19 reduces economic activity, which reduces pollution, which saves lives. Retrieved from Global Food, Environment and Economic Dynamics: http://www.g-feed.com/2020/03/covid-19-reduces-economicactivity.html

[11] Burke, R.M., Midgley, C. M., Dratch, A., Fenstersheib, M., Haupt, T., Holshue, M., Ghinai, I., Jarashow, M. C., Lo, J., McPherson, T. D., Rudman, Sarah Scott, S. S., Hall, A. J., Fry, A. M., and Rolfes, M. A. (2020). Active Monitoring of Persons Exposed to Patients with Confirmed COVID-19 - United States, January-February 2020 U.S. Department of Health and Human Services/Centers for Disease Control Morbidity and Mortality Weekly Report (69) 9, 2465-246.

[12] Callaway, E., Cyranoski, D., Mallapaty, S., Stoye, E., and Tollefson, J. (2020). Coronavirus by the numbers. Nature (579) 482-483.

[13] Cassella, C. (2020). The World's Facing a Silent Pandemic More Dangerous Thank Most Viruses: Air Pollution. https://www.sciencealert.com/air-pollution-is-far-moredangerous-than-all-the-violence-in-the-world-study-shows

[14] Center on Budget and Policy Priorities. (2020). https://www.cbpp.org/longest-economic-expansion-onrecord-endangered-by-covid-19

[15] Center for strategic and international studies (CSIS). (2020). The Global Economic Impacts of COVID-19. https://www.csis.org/analysis/global-economic-impactscovid-19

[16] Chen, N., Zhou, M., Dong, X., Qu, J., Gong, F., Han, Y., Qiu, Y., Wang, J., Liu, Y., Wei, Y., Xia, J., Yu, T., Zhang, X., Zhang, L. (2020). Epidemiological and clinical characteristics of 99 cases of 2019 novel coronavirus pneumonia in Wuhan, China: a descriptive study. The Lancet (395) 507-513.

[17] Chinadaily.com, (2020). SOE to build medical waste disposal center in Wuhan. https://www.chinadaily.com.cn/a/202002/07/WS5e3d152ca31 0128217275d44.html

[18] Cucinotta, D., and Vanelli, M., (2020). WHO Declares COVID-19 a Pandemic. Acta Biomedica (91) 1, 157-160.

[19] Cullen MT. (2020). Coronavirus Food Supply Chain Under Strain What to do? Food Systems Transformation.

[20] Cyranoski, D. (2020) What China's Coronavirus Response Can Teach the Rest of the World. Nature (579) 479-480.

[21] Duffin, E. (2020a). • U.S.: real GDP growth by quarter 20112019 Statista. $\quad$ Retrieved from https://www.statista.com/statistics/188185/percent-changefrom-preceding-period-in-real-gdp-in-the-us/

[22] Duffin, E. (2020b). - U.S. unemployment rate: adjusted, September $2020 \quad$ Statista. Retrieved from https://www.statista.com/statistics/273909/seasonallyadjusted-monthly-unemployment-rate-in-the-us/

[23] EPA. United States Environmental Protection Agency. (2006). Solid waste management and greenhouse gases: A life-cycle assessment of emissions and sinks. Third edition. Washington, DC.

[24] EPA. (2020, April 1). United States Environmental Protection Agency. Retrieved from Basic Information about NO2: https://www.epa.gov/no2-pollution/basic-information-aboutno2\#Effects

[25] Food And Agricultural Organization (FAO). (2020). How is COVID-19 pandemic - impact on food and agriculture.

[26] Forbes. https://www.forbes.com/sites/davidblackmon/2020/06/07/ope c-extension-sets-up-very-favorable-oil-price-conditions-forthe-rest-of-2020/\#296775cc4507

[27] Forbes.com. https://www.forbes.com/sites/chuckjones/2020/03/30/coronav irus-could-wipe-out-over-seven-years-of-job-growth-with-17million-people-laid-off/\#2ddcf1cd42a1

[28] Forstadt J. (2020). Dairy Industry Upended By COVID 19

[29] Ghinai, I., McPherson, T. D., Hunter, J. C., Kirking, H. L., Christiansen, D., Joshi, K., Rubin, R., Morales-Estrada, S., Black, S. R., Pacilli, M., Fricchione, M. J., Chugh, R. K., Walblay, K. A., Ahmed, N. S., Stoecker, W. C., Hasan, N. F., Burdsall, D. P., Reese, H. E., Wallace, M., Wang, C., Moeller, D., Korpics, J., Novosad, S. A., Benowitz, I., Jacobs, M. W., Dasari, V. S., Patel, M. T., Kauerauf, J., Charles, E. M., Ezike, N. O., Chu, V., Midgley, C. M., Rolfes, M. A., Gerber, S. I., Lu, X., Lindstrom, S., Verani, J. R., Layden, J. E., for the Illinois COVID-19 Investigation Team. (2020). First known person-to-person transmission of severe acute respiratory syndrome coronavirus 2 (SARS-CoV-2) in the USA. The Lancet (395) 1137-1144.

[30] Global Food Crisis Report. (2020). https://www.fsinplatform.org/sites/default/files/resources/files /GRFC_2020_ONLINE_200420.pdf

[31] Goeb, J., Zu, A.M., Synt, N.L.K., Zone, P.P., Boughton, D. and Maredia, M.K., (2020). Monitoring the impact of COVID-19 in Myanmar: Agricultural commodity Traders-Late June 2020 survey round (Vol. 23). Intl Food Policy Res Inst.

[32] Headey, D.D. and Ruel, M.T., (2020). The COVID-19 nutrition crisis: What to expect and how to protect. IFPRI book chapters, pp.38-41.

[33] Heath, R. (2020, March 13). Emissions are down thanks to coronavirus, but that's bad. Retrieved April 2, 2020, from https://www.politico.com/news/2020/03/13/climateadvocates-hit-political-turbulence- 127649

[34] Henriques M (2020) Will Covid-19 have a lasting impact on the environment? 27th March 2020, https://www.bbc.com/future/article/20200326-covid-19-theimpact-of-coronavirus-on-theenvironment, accessed on 29 March 2020

[35] Holshue, M. L., DeBolt, C., Lindquist, S., Lofy, K. H., Wiesman, J., Bruce, H., Spitters, C., Ericson, K., Wilkerson, S., Tural, A., Diaz, G., Cohn, A., Fox, L., Patel, A., Gerber, S. I., Kim, L., Tong, S., Lu, X., Lindstrom, S., Pallansch, M. A., 
Weldon, W. C., Biggs, H. M., Uyeki, T. M., and Pillai, S., for the Washington State 2019-nCoV Case Investigation Team. First Case of 2019 Novel Coronavirus in the United States (2020). The New England Journal of Medicine (328) 10, 929936.

[36] Huang, L., Zhang, X., Zhang, X., Wei, Z., Zhang, L., Xu, J., Liang, P., Yuanhong Xu, Y., Zhang, C., and Xu, A. (2020b). Rapid asymptomatic transmission of COVID-19 during the incubation period demonstrating strong infectivity in a cluster of youngsters aged 16-23 years outside Wuhan and characteristics of young patients with COVID-19: A prospective contact-tracing study. Journal of Infection (80) e1e13.

[37] Huang, C., Wang, Y., Li, X., Ren, L., Zhao, J., Hu, Y., Zhang, L., Fan, G., Xu, J., Gu, X., Cheng, Z., Yu, T., Xia, J., Wei, Y., Wu, W., Xie, X., Yin, W., Li, H., Liu, M., Xiao, Y., Gao, H., Li Guo, Xie, J., Wang, G., Jiang, R., Gao, Z., Jin, Q., Wang, J., and Cao, B. (2020a). Clinical features of patients infected with 2019 novel coronavirus in Wuhan, China. Lancet (395) 497506.

[38] Hui, D. S., Azhar, E. I., Madani, T. A., Ntoumi, F., Kock, R., Dar, O., Ippolito, G., Mchugh, T. D., Memish, Z. A., Drosten, C., Zumula, A., and Petersen, E. (2020). The continuing 2019$\mathrm{nCoV}$ epidemic threat of novel coronaviruses to global health - The latest 2019 novel coronavirus outbreak in Wuhan, China. International Journal of Infectious Diseases (91) 264266.

[39] Jiangtao, S., \& Zheng, W. (2020, March 5). As tonnes of used masks pile up, China struggles to cope with medical waste. Retrieved April 9, 2020, from https://www.scmp.com/news/china/society/article/3065049/c oronavirus-china-struggling-deal-mountain-medical-wastecreated

[40] Jones, C. (2020, March 30). Coronavirus Could Wipe Out Over Seven Years Of Job Growth With 17 Million People Laid Off. Retrieved from Forbes: https://www.forbes.com/sites/chuckjones/2020/03/30/coronav irus-could-wipe-out-over-seven-years-of-job-growth-with-17million-people-laid-off/\#2b54652442a1

[41] Li, Q., Guan, X., Wu, P., Wang, X., Zhou, L., Tong, Y., Ren, R., Leung, K. S. M., Lau, E. H. Y., Wong, J. Y., Xing, X., Xiang, N., Wu, Y., Li, C., Chen, Q., Li, D., Liu, T., Zhao, J., Liu, M., Tu, W., Chen, C., Jin, L., Yang, R., Wang, Q., Zhou, S., Wang, R., Liu, H., Luo, Y., Liu, Y., Shao, G., Li, H., Tao, Z., Yang, Y., Deng, Z., Liu, B., Ma, Z., Zhang, Y., Shi, G., Lam, T. T. Y., Wu, J. T., Gao, G. F., Cowling, B. J., Yang, B., Leung, G. M., and Feng, Z. (2020). Early Transmission Dynamics in Wuhan, China, of Novel Coronavirus-Infected Pneumonia. The New England Journal of Medicine (382) 13 1199-1207.

[42] Ivanov, D. (2020). Predicting the impacts of epidemic outbreaks on global supply chains: A simulation-based analysis on the coronavirus outbreak (COVID-19/SARS-CoV-
2) case. Transportation Research Part E: Logistics and Transportation Review, 136, 101922.

[43] Laborde D. (2020). International Food Policy Research Institute Food Export Restrictions during the Covid-19 crisis. https://public.tableau.com/profile/laborde6680\#!/vizhome/Ex portRestrictionsTracker/FoodExportRestrictionsTracker;

[44] Laborde, D., Martin, W., Swinnen, J. and Vos, R., (2020a). COVID-19 risks to global food security. Science, 369(6503), pp.500-502.

[45] Laborde, D., Martin, W. and Vos, R., (2020b). Poverty and food insecurity could grow dramatically as COVID-19 spreads. Research Post, April, 16, p.2020.

[46] Liu, J., Liao, X., Qian, S., Yuan, J., Wang, F., Liu, Y., Wang, Z., Wang, F-S., Liu, L., Zhang, Z. (2020). Community Transmission of Severe Acute Respiratory Syndrome Coronavirus 2, Shenzhen, China, 2020. Emerging Infectious Diseases (26) 6 1320-1323.

[47] Marlow S. (2020). Effects on the Fertilizer Industry. HIS Markit.

[48] Maier, B. F., \& Brockmann, D. (2020). Effective containment explains subexponential growth in recent confirmed COVID19 cases in China. Science, 368(6492), 742-746.

[49] McGrath, M. (2020). Coronavirus: Air pollution and CO2 fall rapidly as virus spreads. https://www.bbc.com/news/scienceenvironment-51944780

[50] Moghadas, S. M., Fitzpatrick, M. C., Sah, P., Pandey, A., Shoukat, A., Singer, B. H., \& Galvani, A. P. (2020). The implications of silent transmission for the control of COVID19 outbreaks. Proceedings of the National Academy of Sciences, 117(30), 17513-17515.

[51] Myllyvirta, L. (2020, February 19). Carbon Brief: Clear on Climate. Retrieved from Analysis: Coronavirus temporarily reduced China's $\mathrm{CO} 2$ emissions by a quarter: https://www.carbonbrief.org/analysis-coronavirus-hastemporarily-reduced-chinas-co2-emissions-by-a-quarter

[52] Nepali Sansar. (2020). COVID-19 Inflicts NPR 2 Bn Loss on Nepal Dairy Industry!

[53] Network, T. B. (2020). Coronavirus: Impacts on wildlife and climate [Recorded by E. China]. [Podcast]. Retrieved March 1, 2020 , from https://environmentchinapod.libsyn.com/coronavirusimpacts-on-wildlife-and-climate

[54] NRDC. (2020). Single-Use Plastics 101. https://www.nrdc.org/stories/single-use-plastics-101

[55] O'Callaghan, K. P, Blatz, A. M., and Offit, P. A. (2020) Developing a SARS-CoV-2 Vaccine at Warp Speed Journal of the American Medical Association (324) 5 437-438.

[56] Phan, T. V. and Pham V. N. (2020). Importation and Humanto-Human Transmission of a Novel Coronavirus in Vietnam. The New England Journal of Medicine (382) 9 872-873.

[57] Politico Report. (2020). Emissions are down thanks to coronavirus, but that's bad. 
https://www.politico.com/news/2020/03/13/climateadvocates-hit-political-turbulence-127649

[58] Poudel, P. B., Poudel, M. R., Gautam, A., Phuyal, S., Tiwari, C. K., Bashyal, N., \& Bashyal, S. (2020). COVID-19 and its Global Impact on Food and Agriculture.

[59] Research, N. B. of E. (2020). Longest Economic Expansion on Record Ended by COVID-19 | Center on Budget and Policy Priorities. Retrieved October 20, 2020, from https://www.cbpp.org/longest-economic-expansion-onrecord-endangered-by-covid-19

[60] Ritchie, H. and Roser M. (2019). Air pollution is one of the world's leading risk factors for death. https://ourworldindata.org/air-pollution

[61] Ritchie, H., \& Roser, M. (2017). Air Pollution. Our World in Data. Retrieved from https://ourworldindata.org/air-pollution

[62] Ross, J. (2020, March 26). COVID-19 Crash: How Chinas Economy May Offer a Glimpse of the Future. Retrieved April 2, 2020, from https://www.visualcapitalist.com/covid-19economic-impact/

[63] Rudden, J. (2020). • Weekly DJIA index performance 2020 | Statista. Retrieved from https://www.statista.com/statistics/1104278/weeklyperformance-of-djia-index/

[64] Scudellari, M. (2020). The sprint to solve coronavirus protein structures - and disarm them with drugs. Nature, 581(7808), 252-255.

[65] Siche, R. (2020). What is the impact of COVID-19 disease on agriculture? Scientia Agropecuaria, 11(1), 3-6.

[66] Tan, P. H., Chou, C., Liang, J. Y., Chou, C. C. K., \& Shiu, C. J. (2009). Air pollution "holiday effect" resulting from the Chinese New Year. Atmospheric Environment, 43(13), 2114 2124. https://doi.org/10.1016/j.atmosenv.2009.01.037

[67] Temple, J. (2020). What does the coronavirus outbreak mean for climate change? https://www.technologyreview.com/2020/03/25/950315/radio -corona-so-what-about-climate-change/

[68] Temple, J. (2020, March 13). Why the coronavirus outbreak is terrible news for climate change. Retrieved April 2, 2020, from https://www.technologyreview.com/s/615338/coronavirusemissions-climatechange $/$ truid $=6 \mathrm{ad} 81 \mathrm{~b} 404 \mathrm{c} 4655 \mathrm{~d} 3 \mathrm{beb} 42 \mathrm{cff} 93 \mathrm{f} 48784 \& \mathrm{utm} \_\mathrm{s}$ ource=the_download\&utm_medium $=$ email\&utm_campaign $=\mathrm{t}$ he_download.unpaid.engagement\&utm_content=03-12-2020

[69] Theguardian.com. (2020). Polluter bailouts and lobbying during COVID-19 pandemic. https://www.theguardian.com/environment/2020/apr/17/pollu ter-bailouts-and-lobbying-during-covid-19-pandemic

[70] Theverge.com. (2020). The COVID-19 pandemic is generating tons of medical waste. https://www.theverge.com/2020/3/26/21194647/the-covid19-pandemic-is-generating-tons-of-medical-waste

[71] Torero M. (2020). Without food, there can be no exit from the pandemic. Countries must join forces to avert a global food crisis from COVID-19. Nature. 2020; 580:588-589. doi: 10.1038/d41586-020-01181-3.

[72] Wallerlaw.com. (2020). https://www.wallerlaw.com/newsinsights/3497/Providers-press-for-financial-assistance-fromfederal-government.

[73] Wan, Y., Shang, J., Graham, R., Baric, R. S., and Lia, F. (2020). Receptor Recognition by the Novel Coronavirus from Wuhan: An Analysis Based on Decade-Long Structural Studies of SARS Coronavirus. Journal of Virology (94) 7, 1-9.

[74] Ward, M. (2020, April 6). Tesla, Apple, and Ford are stepping up to address global shortages of ventilators, hand sanitizer, face masks, and gowns. Here's a running list of companies helping out. Retrieved April 9, 2020, from https://www.businessinsider.com/coronavirus-companieshelping-meet-shortages-of-ventilators-gowns-masks-handsanitizer-healthcare\#snap-lab-the-hardware-company-behindsnap-incs-spectacles-is-producing-medical-face-shields-16

[75] World Health Organization (2020a). Statement on the second meeting of the International Health Regulations (2005) Emergency Committee regarding the outbreak of novel coronavirus (2019-nCoV). Retrieved from https://www.who.int/news-room/detail/30-01-2020statement-on-the-second-meeting-of-the-international-healthregulations-(2005)-emergency-committee-regarding-theoutbreak-of-novel-coronavirus-(2019-ncov)

[76] World Health Organization (2020b). Statement on the second meeting of the International Health Regulations (2005) Emergency Committee regarding the outbreak of novel coronavirus (2019-nCoV). Retrieved from https://www.who.int/news-room/detail/30-01-2020statement-on-the-second-meeting-of-the-international-healthregulations-(2005)-emergency-committee-regarding-theoutbreak-of-novel-coronavirus-(2019-ncov)

[77] World Health Organization (2020c) Weekly Epidemiological Update - 20 October 2020. Retrieved: https://www.who.int/publications/m/item/weeklyepidemiological-update---20-october-2020

[78] Wu, F., Zhao, S., Yu, B., Chen, Y-M., Wang, W., Song, Z-G., Hu, Y., Tao, Z-W., Tian, J-H., Pei, Y-Y., Yuan, M-L., Zhang, Y-L., Dai, -H., Liu, Y., Wang, Q-M., Zheng, J-J., Xu, L., Holmes, E. C., and Zhang, Y-Z., (2020). A new coronavirus associated with human respiratory disease in China. Nature (579) 265-271.

[79] Zhang, X. (2020). Chinese livestock farms struggle under COVID-19 restrictions. IFPRI book chapters, 84-85.

[80] Zhou, P., Yang, X-L., Wang, X-G., Hu, B., Zhang, L., Zhang, W., Si, H-R., Zhu, Y., Li, B., Huang, C-L., Chen, H-D., Chen, J., Luo, Y., Guo, H., Jiang, R-D., Liu, M-Q., Chen, Y., Shen, X-R., Wang, X., Zheng, X-S., Zhao, K., Chen, Q-J., Deng, F., Liu, L-L., Yan, B., Zhan, F-X., Wang, Y-Y., Xiao, G-F., and Shi, Z-L. (2020). A pneumonia outbreak associated with a new coronavirus of probable bat origin. Nature (579) 270-275. 